\title{
RENEWABLE ENERGY POTENTIAL FOR STRENGTHENING THE ENERGY SECURITY IN EAST SUMBA-SUMBA ISLAND ZONE
}

\author{
YULIANTO BUDI ${ }^{1}$, MAARIF SYAMSUL ${ }^{1}$, HARDJOMIDJOJO HARTRISARI $^{1}$ \& WIJAYA CHANDRA $^{2}$ \\ ${ }^{1}$ Bogor Agriculture Institute Business School, Indonesia. \\ ${ }^{2}$ Department of Business Administration, Faculty of Administrative Science, Universitas Indonesia, Indonesia.
}

\begin{abstract}
Sumba Island has been dubbed as the Iconic Island of renewable energy (RE). However, the realisation of such title has yet to go smoothly and optimally, and it has been faced with manifold hurdles, especially those in relation to the programme continuity; even the electrification rate realised fell short of the rate target. This research aimed to analyse the RE with the highest potential that could be developed to strengthen the energy security of the Sumba Timur-Sumba Island zone. This research employed a hard system approach, namely, the Technique for Order of Preference by Similarity to Ideal Solution (TOPSIS), a multi-criteria decision-making (MCDM) method. Primary data were collected from filling out expert-justified questionnaire. The experts were selected on purpose based on the criteria that they should have full understanding of the conditions and potential of renewable energy sources in Sumba Timur, be sufficiently experienced and be professional. The TOPSIS method was employed for the purpose of determining which RE source has the most potential according to the renewable energy security index. This study involved 30 experts and practitioners, comprising 11 government officials (G), eight businessmen (B), five academics/researchers (A), four community members (C) and two finance agency employees. The results showed that solar energy is the most promising and possible energy source to be developed in East Sumba in the context of strengthening renewable natural resource-based energy source, while other potential alternative energy sources are hydro energy and wind energy.
\end{abstract}

Keywords: East Sumba, natural resources, renewable energy, solar energy, TOPSIS.

\section{INTRODUCTION}

The sun is shining throughout the year in Indonesia. This country has abundant solar, geothermal, hydro power, and wind energies, with characteristics and morphology suiting the utilisation of ocean currents, vast land and climate suiting bioenergy development. However, this potential has yet to be developed optimally. With such enormous energy potential, it is important to select which energy source is best and right to develop in order to support the energy security of a region or zone towards sustainability. The feasibility of investment in the use of such energy must also be considered. This requires greater attention of the government and all stakeholders, especially private sector enterprises, to realise sustainable renewable energy (RE) development affordable and acceptable to the community [1]. The energies with the highest development potential are wind energy and solar energy, but the utilisation is yet to be optimal, only reaching below $0.05 \%$ (Table 1 ).

$\mathrm{RE}$ is admittedly not the best alternative for every country for reasons such as limited land area or competition of use for other purposes. However, this seems to be different for countries with extensive land area such as Brazil, Canada, Thailand, Indonesia and Nigeria. These countries have a lot of alternatives to generate RE, such as bioenergy, solar energy, hydro power and wind energy [2].

Electrical power availability is indispensable. It highly determines the economic development and betterment of quality of life. Electrical use is the key factor in the success of 
Table 1: Indonesia's renewable energy potential, 2016.

\begin{tabular}{|c|c|c|c|c|}
\hline No. & Energy types & Potential & Rated capacity (MW) & Utilisation (\%) \\
\hline 1. & Geothermal & $29,544 \mathrm{MW}$ & 1438.5 & 4.9 \\
\hline 2. & Hydro power & 75,091 MW & 4826.7 & 6.4 \\
\hline 3. & $\begin{array}{l}\text { Mini and micro hydro } \\
\text { power }\end{array}$ & 19,385 MW & 197.4 & 1.0 \\
\hline 4. & Bioenergy & 32,654 MW & 1671.0 & 5.1 \\
\hline 5. & Solar & $\begin{array}{l}207,898 \mathrm{MW} \\
(\geq 4 \mathrm{~m} / \mathrm{s})\end{array}$ & 78.5 & 0.04 \\
\hline 6. & Wind & $60 \mathrm{GW}$ & 3.1 & 0.01 \\
\hline 7. & Ocean current & $17,989 \mathrm{MW}$ & 0.3 & 0.002 \\
\hline
\end{tabular}

Source: Presidential Regulation No. 22 of 2017 on General Planning on National Energy.

agricultural and industrial processes towards greater efficiency. It is vital to households (for cooking, lighting, cooling and home-based activities) and to other major facilities such as hospitals, schools and industries. Energy consumption and availability are important issues that can be directly linked to income, standard of living and poverty. The reason is that limited energy availability and energy unreliability are closely related to the standard of living and poverty, limited job opportunities and poor economic conditions, setting the primary barriers to the economic growth of a country.

The title 'Iconic Island' was bestowed for Sumba Island based on some considerations from the study by Hivos in 2012. Sumba Island has low access to modern energy (an electrification rate of 24.5 in 2010). Second, Sumba Island is dependent on the energy generated by a diesel power plant from another region at a rate of $85 \%$, thereby incurring high transportation cost. Third, Sumba Island is rich in RE potential sources, for example, hydro power, bioenergy, wind energy and solar energy [3]. As Lomi stated, the electrification rate of Sumba Island as of 2015 only reached $45.60 \%, 10.42 \%$ of which was contributed by RE power plants [4]. The electrification rate of Sumba Timur Regency was 59.87\% in 2015, Sumba Tengah and Sumba Barat regencies 38.38\% and Sumba Barat Daya Regency was $43.89 \%$. However, according to recent verification and validation conducted by researchers in September 2018, the electrification rate, especially of Sumba Timur, was way below the numbers reported by previous research.

Based on Sumba's roadmap as the Iconic Island of RE of 2020, the electricity which is needed on Sumba Island touched a value of $62.9 \mathrm{MW}, 43.381 \mathrm{MW}$ of which was new and RE, while the remaining $19.518 \mathrm{MW}$ was diesel/gas energy (PLTD/MG). Hence, to meet the electrification rate target of $95 \%$ in 2020 with contribution from new and RE being 65\%, an extra $50 \mathrm{MW}, 37.5 \mathrm{MW}$ of which is new and RE, will be needed. With an electrification rate of $45.60 \%$ in 2015, it is expected that Sumba will have an average electrification rate increase of $4.192 \%$ per annum. If related to the total installed capacity of plants on the island of Sumba which reaches 17.53 MW (11.6 MW PLTD and 5.928 MW EBT), at least an additional 7.5 MW of power plants is needed per year until 2020. But based on our observations, the realisation of Sumba as an RE Icon is not running smoothly and optimally. It has many problems, especially related to programme sustainability; even the electrification ratio is not 
as large as targeted. In fact, many found the projects stalled and abandoned. To follow the Sumba the Iconic Island of RE programme up and to optimise the existing potential, especially that in Sumba Timur, we felt it necessary to conduct this study. This research aimed to analyse the RE with most potential to develop in order to strengthen the energy security in the Sumba Timur-Sumba Island zone.

The aims of the research are to: assess the condition of energy security in the East Sumba zone on Sumba Island which will be used as a model for the design of an independent energy security zone by utilising the potential of renewable natural resource-based energy available in the area; assess the potential for energy based on the most promising renewable natural resources to be developed in strengthening the energy security of the East Sumba zone on Sumba Island; describe and analyse the problems that hamper the private sector's role in developing renewable natural resource-based energy on Sumba Island, especially in the East Sumba zone; and design and recommend business models that can be implemented as an effort to strengthen the role of the private sector in the development of energy security zones based on renewable natural resources in the East Sumba zone in synergy with the government, community, financial institutions and academics/researchers.

The methods used include the Eckenrode method with RE security indicators to determine the size of the East Sumba zone energy security index and the Technique for Order of Preference by Similarity to Ideal Solution (TOPSIS) to determine RE based on the most promising and possible natural resources.

\section{LITERATURE REVIEW}

\subsection{Energy security concept}

The understanding of the concept of energy security has shifted from only about supply availability to also covering the concept of sustainability and resilience in securing and managing energy resources. The energy security concept that takes the aspect of environmental impacts into consideration has exerted influence on the ideas of more intensified RE technology development, leading to energy conservation, recently better known as energy security concept.

Energy security, in general, can be defined as availability with indicators including source of supply, affordability - purchasing power correlated to national income per capita - and accessibility for energy users to propel life and economic cycle [5].

The International Energy Agency (IEA) [6] defines energy security as 'the uninterrupted availability of energy sources at an affordable price'. Energy security comes with multiple aspects. Long-term energy security is primarily tied to timely investment to supply energy in accordance with the economic development and environmental needs. Meanwhile, shortterm energy security focuses on the energy system's ability to promptly react to sudden changes in the supply-demand balance.

The establishment of energy security aspects was based on Asia Pacific Energy Research Center (APERC), encompassing availability, affordability, accessibility and acceptability. Meanwhile, the establishment of components and indicators was based on the World Energy Council, Center for Energy Resources Development Technology (BPPT) and National Security Agency (LEMHANAS) and is related to the data availability. Especially for the components and indicators, respondents were given a room to add to, rule out or revise the components and indicators presented. 
The energy security aspects used based on the calculated dominant variables include the following four aspects: availability, which indicates the availability of energy, either fossil energy such as oil, gas and coal energy or RE such as solar energy, wind power, energy from waste, micro hydro power and so forth; affordability or community's ability to utilise energy, which indicates consumers' ability to pay for the price of the energy needed for building energy infrastructure and energy management; accessibility, which indicates the ease of access to energy resources in their final forms and acceptability, which indicates the accessibility of the energy provided for the community.

Based on the 4A aspects - availability, accessibility, affordability and acceptability - a further review was undertaken to generate sustainable RE security indicators. The different kinds of energies used by the public, infrastructure, level of energy utilisation and environment were also taken into consideration. According to the Indonesia National Energy Council and stakeholders in the energy sector and based on various considerations according to the aforementioned four aspects, 18 energy security indicators were determined. Affordability indicators include energy productivity, oil fuel/liquid petroleum gas (LPG) price, electricity price, natural gas price and coal price [7]. Accessibility indicators include oil fuel/LPG provision, electricity provision, natural gas provision and coal provision. Availability indicators include oil fuel/LPG import, crude oil import, domestic gas obligation (DMO) coal and natural gas, oil and gas reserves and resources, coal reserves and resources, and new and RE reserves and resources. Lastly, acceptability indicators include achievement of energy mix, decrease in greenhouse gas emissions and public acceptability. In this research, particular to new and RE security, the indicators differed and were subject to a couple of adjustments. In total, the indicators of the four aspects numbered 26 [8].

The energy security rating was done in a scale of four categories, including low, medium, good and high. The value range for the category low was $0 \leq 6$, for medium $6 \leq 7$, for good $7 \leq 8$ and for high $8-10$. From the calculation of the energy security indicators using the analytical hierarchy process (AHP), a value of 7.518 was obtained for Indonesia's energy security, and this value was considered as good.

Energy security is uninterrupted energy source availability at an affordable price. It is deemed important as energy constitutes a pivotal component in goods and services production. The obstacles and interruptions may impede the supply of energy of primary fuels (oil fuels, gas and coal) or electricity, can decrease the economic productivity of a region and if the magnitude of the interruptions reaches a national level, it can cause the economic growth to stray from the set target. This is in line with the concept of energy security defined by the IEA as well as the basic theory of microeconomics. According to Azmi and Amir [9], there are three foundational components in the maintenance of energy supply sustainability: (1) precise estimation of energy demand as a basis for energy supply planning, (2) reliability of energy supply undertaken by a business entity and (3) energy price signalling the business entity to get involved in the energy provision. Energy price assumes a substantial importance as it will be used by producers to estimate the return on the investment made for energy provision.

With regard to policy, the government has enacted Presidential Regulation No. 5 of 2006 on National Energy Policies with the aim of ensuring domestic energy supply security. Some of the policy targets for 2025 set forth under the presidential regulation in detail include realisation of energy elasticity of below 1, reduction of oil fuel portion in the primary energy composition by up to $20 \%$, optimisation of coal fuel and gas fuel by more than $33 \%$ and $30 \%$, respectively, and developing new and RE sources. To meet such targets, two policies are established: (1) the main policy based on specifying provision, utilisation, pricing and natural 
Table 2: Index and scores of energy sustainability balance in Indonesia.

\begin{tabular}{llllll}
\hline & \multicolumn{5}{c}{ Year } \\
& $\mathbf{2 0 1 6}$ & $\mathbf{2 0 1 7}$ & $\mathbf{2 0 1 8}$ & Trend & Score \\
\hline Energy performance & 85 & 75 & 71 & & \\
Energy security & 63 & 59 & 61 & $\rightarrow$ & B \\
Energy equity & 88 & 82 & 82 & $\rightarrow$ & B \\
Environmental sustainability & 77 & 68 & 57 & $\uparrow$ & B \\
Contextual performance & 77 & 83 & 80 & $\rightarrow$ & \\
Political power & 95 & 93 & 90 & $\downarrow$ & \\
Social power & 78 & 75 & 72 & $\rightarrow$ & \\
Economic power & 42 & 43 & 39 & $\downarrow$ & \\
Overall score and balance score & 85 & 75 & 71 & $\rightarrow$ & BBB \\
\hline
\end{tabular}

Source: World Energy Trilemma Index 2018 and World Economic Forum 2018.

conservation and (2) a supporting policy addressing infrastructure development, public-private partnership and community empowerment.

A good state is one that has high energy security. Based on the Energy Sustainability Index set by the World Energy Trilemma, Indonesia became the world's 71st in 2018, which was lower than its 75th position in 2017. It rose from the 85th position in 2016 (Table 2) [10].

The management and development of the electricity sector always pays attention to the 'energy trilemma', namely, energy security, energy equity and environmental sustainability. Regarding 'energy security', the implementation is carried out among others by increasing the capacity of generators and increasing the availability of electricity, while with regard to 'energy equity', this is done via increased accessibility through fair distribution, which is reflected in an increase in the electrification ratio and affordable electricity prices. As for 'environmental sustainability', its implementation is carried out in a way that aside from having to be reliable and of high quality, electricity infrastructure development must also be environmentally friendly. The greater the degree to which the elements above can be met, the stronger our energy security. When comparing renewable and non-renewable energy, the use of RE will increase energy security.

\subsection{RE zone}

RE is the energy generated from sustainable sources of energy such as the heat of the Earth, wind, bioenergy, solar radiation, water current, waterfall and movements caused by difference in the temperatures of different layers of the ocean. The source of energy that can be recovered by nature in a relatively short time period is called renewable. It needs a push in competitiveness as it needs to be subsidised to stay competitive against fossil fuels in terms of cost, although it is worth mentioning that the development of RE technologies continuously encourages price reduction, and it is only a matter of time until RE gains higher competitiveness in terms of price without subsidy than traditional fuels.

Aside from cost, efficiency improvement should also be considered in the development of RE. For instance, a solar panel has $15 \%$ efficiency on average, meaning that much energy is 
wasted and transferred into heat instead of usable form of energy. Nevertheless, many research studies are currently carried out with the purpose of improving the efficiency of RE technologies, some of which are absolutely promising, although any remarkably efficient RE solution that is of a considerable commercial value has yet to be seen. One of the studies that conducted research on RE was Barzola et al. [11], where the analysis of solar, wind and RE systems for rural electricity was reviewed. Their research discussed the application of the proposed power generation system from RE that is important in people's lives. It was also explained that this energy system helped reduce greenhouse gas emissions to the environment and the impact on climate change.

A zone or area is defined as a geographical unit along with the elements relevant to it, whose boundaries and system are determined based on administrative aspects and/or functional aspects. The zones are areas with RE potential. Thus, an energy sustainability zone can be defined as an area/zone/cluster with an energy supply that is available in sufficient quantity, at an affordable price, and is easy to access, environmentally friendly and sustainable.

The employment of the multi-criteria decision analysis (MCDA) in conjunction with the geographical information system (GIS) to assess energy development potential and inform land use planning process, both for a conventional energy project and an RE project, has a long history. Some academic studies have applied the methodology variant GIS-MCDA to tackle certain site designation challenges and answer whether certain technological policy targets can be met by the land available $[12,13]$.

Several significant RE zoning studies for transmission planning purposes have been carried out for the United States. Some of the most prominent are the California RE Zones designated by the California Public Utilities Commission [14], the Energy Zones for Eastern Interconnection designated by the Argonne National Laboratory [15] and the Texas Competitive RE Zones (CREZs) designated by the Public Utility Commission of Texas [16]. Some first transmission paths identified and planned through the Texas CREZ projects have begun mitigating congestion in power grids that facilitate wind power transmission in the northwest part of the state to the load centre in the southeast [16]. Meanwhile, some RE potential assessments have been carried out in African states [17]. A study in South Africa is the first in Africa that identified RE development zones to streamline environmental impact assessment application and promote low emissions environment - a process of determining unstable sites more evenly for RE [18].

Multi-criteria Analysis for Planning RE (MapRE) approaches the RE zones for the Africa Clean Energy Corridor (ACEC). This modelling approach uses the frameworks developed in previous resources reviews and zoning studies with some significant improvements and adjustments, especially for computing data limits in African states.

Research by Rijanto and Armawi [19] shows that the Regency of Sumedang has sizeable alternative RE potential in the form of geothermal energy, hydro power/micro-hydro power, biogas or any other energy types, but utilisation of such potential has yet to be optimal. One of the breakthroughs either the central government or local governments can make is engaging private sector enterprises in Corporate Social Responsibility (CSR) for green energy programmes. The governments can formulate policies to regulate private sector enterprises' implementation of alternative energy development programmes. Private sector enterprises' role in the alternative energy development in public-private partnerships will have positive impacts.

Popescu [20] in his study analysed economic components in energy security to examine the concept of energy security from the economic and financial perspectives. In his study, it 
is stated that the energy sector must be dynamic and active in supporting the world's economic development and helping close the gap between countries, especially the developing ones. Oil supply and its related costs have influenced crises worldwide as oil constitutes a modern industrial economic life source. There is a direct correlation between oil price and primary consumer goods prices. When the world's oil price rises or drops, companies will compensate their loss and charge consumers with additional costs, or, if consumers are not to be charged with all of those additional costs, workers will be affected through wage reduction, or worse, employee downsizing.

Kanchana and Unesaki [21] explained that just recently, the Association of Southeast Asian Nations (ASEAN) countries are attempting a regional energy cooperation, and thus, it is crucial to find out how good the energy security performance of such ASEAN member countries is. In their study, they assessed the energy supply security of nine ASEAN countries and checked whether and how it evolves over the past decade. The results demonstrate a difference in concept between the countries. Despite uneven economic and energy development, the existing intraregional energy markets are interrelated. Regional independence concept may be useful for designing and promoting ASEAN collaborations in energy security.

Kulkarni et al. [22] conducted a study on wind energy development in India using a multi-criteria approach. Some factors affecting the operation of wind turbine generators were analysed by eliciting expert opinions and information on the wind turbine generators performance resulted. The analysis method employed was the AHP, which was based on technical, economic, environmental and sociological indicators. A previous study was carried out in the district of Belagavi in the state of Karnataka, India. From the research results, it was estimated that renewable wind-based power plants will become a trend in the coming years. There was a strong relationship between energy availability and the economy of a country. By the methods established, a performance index was developed to evaluate the wind turbine generators cluster with the best performance based on multi-criteria decision-making (MCDM). The best wind turbine generators were the ones in Chikkodi, followed by those in Saundatti, Raibag and Belagavi. Some other decision-making methods employed in that research were TOPSIS, VIKOR and ANP.

Barzola et al. [11] conducted an analysis of solar/wind/diesel hybrid RE system for rural electrification. They proposed a design called Hybrid Electric System (HES) for supplying rural electricity needs, which is placed in Ecuadorian coast. In that research, it is explained that the application of an RE-based power plant system plays a considerable role in the community's lives. It is also highlighted that this energy system helps cut greenhouse gas emissions to the environment and mitigate impacts on climate change. However, there are certain restrictions justifying the use of diesel generators in this system; this is intended for (1) activating electricity during busy hours; (2) supporting the system during periods in which the solar radiation rate and wind speed are low and (3) reducing the cost of electricity $(\mathrm{COE})$ of the system. The detailed conceptual framework of this research is presented in Fig. 1.

\section{METHOD}

This study applied a hard system approach, namely, MCDM, based on the TOPSIS method [23]. Primary data were obtained through filling out questionnaires based on expert justification. The experts were selected on purpose based on the criteria that they should have full understanding of the conditions and potential of the renewable energies in Sumba Timur, be sufficiently experienced and be professional. The TOPSIS method was employed for the 


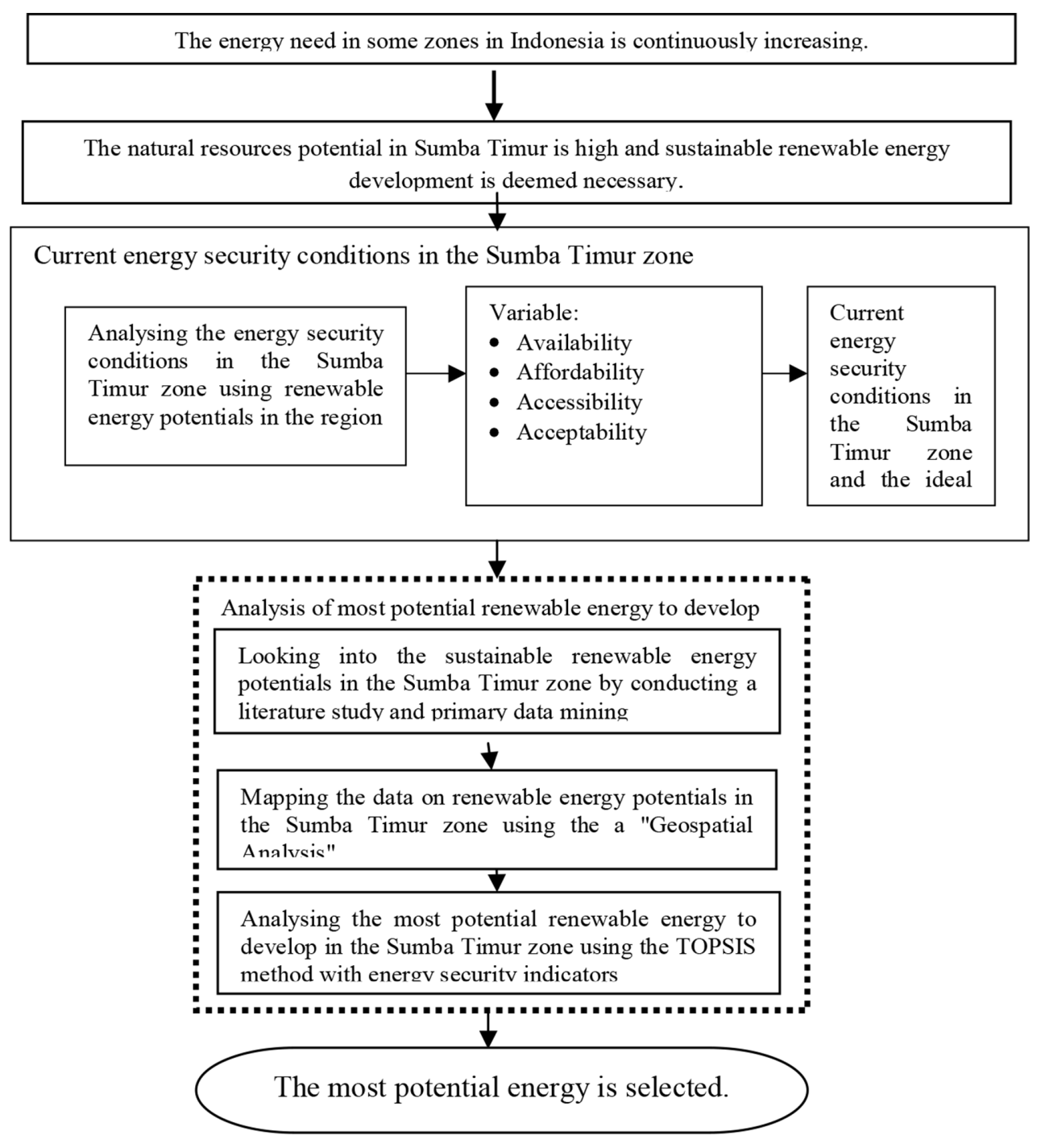

Figure 1: Conceptual framework.

purpose of determining which RE has the highest potential according to the RE security index. The experts or key persons appointed included researchers, academics, businessmen, policy makers, non-governmental agency members or public figures, and financial agency employees in Sumba Timur or in Kupang, the capital city of the province of East Nusa Tenggara. This study involved 30 experts and practitioners, comprising 11 government officials (G), eight businessmen (B), five academics/researchers (A), four community members (C) and two finance agency employees.

The TOPSIS method is based on the best preferred alternative that not only has the shortest distance to the positive ideal solution, but also has the longest distance to the negative ideal solution, using Euclidean distances to determine the relative proximity from an 
alternative to the optimal solution [24]. In this research study, the TOPSIS method was used to set priority alternative energy in the development of RE security zone in Sumba Timur, Sumba Island, based on RE security indicators and criteria, both positive factors and negative ones [8].

\section{RESULTS AND DISCUSSION}

\subsection{Analysis of RE with the highest potential}

RE sources in Sumba Timur, including solar energy, hydro power, biomass, wind energy and biogas, were available in abundance, but the energy security index in this region was still low [8]. Low energy security index was caused by a number of reasons, one of which was the community's low affordability as most people of the community of Sumba Timur were poor. The access to energy was also still perceived as hard by the Sumba Timur people on account of the hilly topography and pasture lands, as well as decentralised community settlements despite Sumba Timur's extensive land area. Supporting infrastructure, such as roads, becomes one of the factors of low security index of Sumba Timur, and the lack of institutionalisation model discourages investors to make investments in this region. As is stated by the head of the local government and the Sumba branch of the State Electricity Company (PLN) representative, the electricity coverage rate only reached $31 \%$.

The results of the determination of weights of RE security aspects (Table 3) and weights of indicators using the Eckenrode method were used as the criteria and weights for assessment of each energy potential in Sumba Timur. The calculation of weight of each energy security criterion/indicator based on the Eckenrode method normally employs MCDM [25], based on TOPSIS. The aspects assessed in this research were affordability (six indicators), accessibility (seven indicators), availability (seven indicators) and acceptability (six indicators) as shown in Table 3. The following are some steps taken in the TOPSIS analysis.

The principal items in setting alternative priority in TOPSIS are the criteria that are used as the basis for decision. To assess the most potential RE to develop to strengthen the energy security in the Sumba Timur zone, it is necessary to determine the weights of the energy security aspects first. The criteria used must fulfil both the positive and negative criteria in accordance with the absolute requisites of the TOPSIS method.

Figure 2 shows the weights of the energy security indicators from the highest to the lowest as follows: (1) supporting government policies on energy provision $(0.086)$; (2) energy availability/continuity assurance $(0.083)$; (3) the community's purchasing power in obtaining energy (0.073); (4) availability of power generation technologies (0.067) and (5) supporting investment of business persons in energy provision (0.061) and so forth.

The importance of the indicators 'supporting government policies on energy provision', 'availability assurance' and 'the community's purchasing power' in the determination of the most potential energy according to the RE security criteria is also evidenced by the findings [26] which state that the keys to RE development are public awareness and government support.

However, it does not necessarily mean that other criteria are worth overlooking. After the weights were obtained from the Eckenrode analysis, a calculation based on the decision matrix of all key persons' assessment of the type of potential renewable energies in Sumba Timur and the criteria set above was carried out. In general, the steps in the TOPSIS method are as follows: 
Table 3: Energy security indicators.

\begin{tabular}{ll}
\hline No. & Criteria \\
\hline 1 & Efficiency of energy utilisation by the community \\
2 & The community's ability to provide energy independently \\
3 & The community's purchasing power in obtaining energy \\
4 & Ability to meet the energy consumption per capita standard \\
5 & Ability to meet the energy needs against population growth rate \\
6 & Ability to meet the energy needs against potential increase in income per capita \\
7 & Increase in renewable energy provision \\
8 & Increase in energy supply quality \\
9 & Renewable energy distribution capacity \\
10 & The ease of obtaining energy \\
11 & Accessibility-supporting infrastructure \\
12 & Strategic energy reserves \\
13 & Distance to energy source \\
14 & Increase in renewable energy use \\
15 & Energy import decrease contribution \\
16 & Energy diversification index (potential energy sources diversity) \\
17 & Energy availability/continuity assurance \\
18 & Availability of power generation technologies \\
19 & Supporting government policies on energy provision \\
20 & Support of investments by business persons in energy provision \\
21 & Use of renewable energy that can reduce greenhouse gas emissions \\
23 & Development of energy infrastructure acceptable to the community \\
\hline & Use of energy that has positive impacts on the community and the environment \\
\hline & The community's readiness in receiving renewable energy \\
\hline
\end{tabular}

Source: Yulianto et al. [8].

- creation of a normalised decision matrix;

- creation of a weighted, normalised decision matrix;

- determination of the positive ideal solution matrix $\left(\mathrm{A}^{+}\right)$and the negative ideal solution matrix $\left(\mathrm{A}^{-}\right)$;

- calculation of the separation measure;

- determination of the distances between every alternative and the positive ideal solution matrix $\left(\mathrm{S}^{+}\right)$as well as the negative ideal solution matrix $\left(\mathrm{S}^{-}\right)$and

- determination of the preferred value for every alternative $\left(\mathrm{C}^{+}\right)$. 


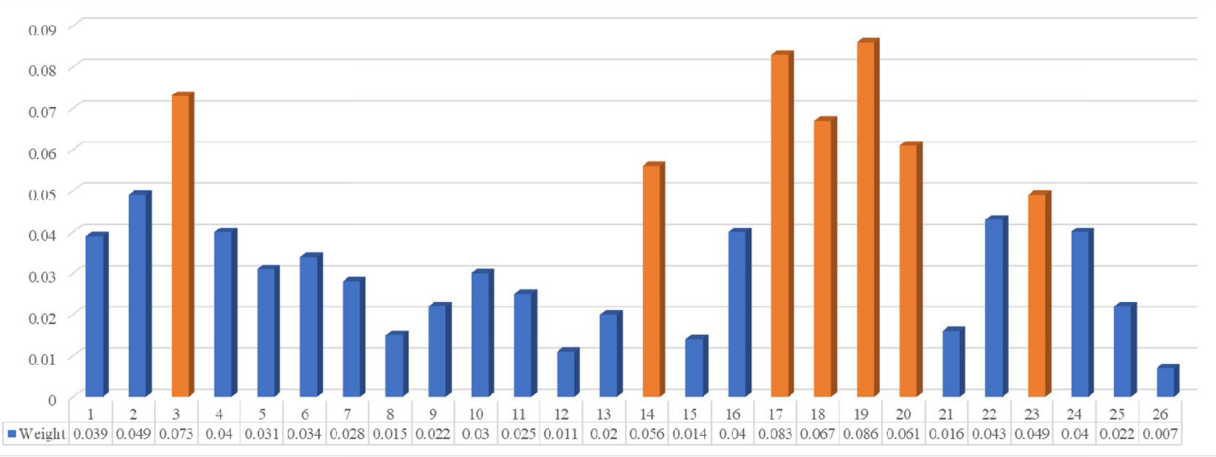

Figure 2: Weights of the energy security indicators.

Note: higher weights.

\subsection{Developing a decision matrix}

The results of justification by 30 key persons were recapped using TOPSIS questionnaires for each energy source alternative based on all indicators as the basis for creating a decision matrix. The final value obtained and processed in the decision matrix is the most frequently occurring value (modus). Such value was then squared to create a normalised decision matrix, resulting in a squared result matrix and a normalised decision matrix. Then, the squared decision matrix values for each criterion were summed, and a calculation was done to find the square root. A calculation for $r_{i j}$ matrix was performed using the following formula:

$$
r_{i j}=\frac{x_{i j}}{\sqrt{\sum_{i=1}^{m} x_{i j}^{2}}}
$$

The value obtained from the $r_{i j}$ matrix calculation was multiplied by the weight of each criterion to obtain the $v_{i j}$ matrix using the following formula:

$$
v_{i j}=w_{i} r_{i j}
$$

This $v_{i j}$ matrix value was used as the positive ideal solution $\left(\mathrm{A}^{+}\right)$and the negative ideal solution $\left(\mathrm{A}^{-}\right)$value.

\subsection{Determining the positive ideal solution $\left(\mathrm{A}^{+}\right)$and the negative ideal solution $\left(\mathrm{A}^{-}\right)$}

The next most important step was determining the positive ideal solution $\left(\mathrm{A}^{+}\right)$and the negative ideal solution $\left(\mathrm{A}^{-}\right)$. To determine the positive ideal solution $\left(\mathrm{A}^{+}\right)$, the maximum value of each potential energy type was calculated based on the positive criteria of the 26 energy security criteria set, while for the negative criteria, the minimum value of the RE type selected was used. On the contrary, to determine the negative ideal solution $\left(\mathrm{A}^{-}\right)$, the minimum values of the five energy types selected based on the positive criteria of the 26 criteria at hand were calculated, while for the negative criteria, the maximum value was used.

\subsection{Calculating the $\mathrm{S}^{+}$and $\mathrm{S}^{-}$values of each element}

The distances between every alternative and the positive ideal solution matrix $\left(\mathrm{S}^{+}\right)$and the negative ideal solution matrix $\left(\mathrm{S}^{-}\right)$were determined. In this section, the total value of each 
energy type selected was calculated based on all criteria (26 indicators of energy security). To calculate the distance between each alternative and the positive ideal solution matrix $\left(\mathrm{S}^{+}\right)$, the total $\mathrm{A}^{+}$value of each potential alternative energy type selected was calculated, while the distance to the negative ideal solution matrix $\left(\mathrm{S}^{-}\right)$was obtained by calculating the total $\mathrm{A}^{-}$value of each potential energy type. In this way, the total value of each potential energy type to be selected could be obtained based on the energy security multi-criteria. The final results were determined by the preference value of each alternative energy type $\left(\mathrm{C}^{+}\right)$as discussed below.

\subsection{Determining the preference value of each alternative $\left(\mathrm{C}^{+}\right)$}

The preference value of each alternative sustainable RE type $(\mathrm{C}+)$ in Sumba Timur is the final determination of the TOPSIS analysis process to select the best, most possible energy source to develop in Sumba Timur using the following formula:

$$
C_{i}^{+}=\frac{S_{i}^{-}}{S_{i}^{+}+S_{i}^{-}}
$$

The preference value for each alternative $\left(\mathrm{C}^{+}\right)$was obtained by dividing the distance between the value of each alternative and the negative ideal solution matrix $\left(\mathrm{S}^{-}\right)$by the total sum of the distance between the value of each alternative and the positive ideal solution matrix $\left(\mathrm{S}^{+}\right)$plus the negative ideal solution matrix $\left(\mathrm{S}^{-}\right)$. The calculation yielded the value of each alternative potential energy $\left(\mathrm{C}^{+}\right)$as outlined in Table 4 , and the highest value was obtained for the solar energy (0.847), followed by hydro power $(0.781)$, wind energy $(0.671)$ and, lastly, geothermal energy. If $\mathrm{S}^{+}$and $\mathrm{S}^{-}$are illustrated in the form of a figure, according to the theory, the best value will be the one with the shortest (smallest) distance to the positive ideal value and the longest (largest) distance from the negative ideal value. This is illustrated in Fig. 2.

Based on the results of the TOPSIS analysis that was aimed to determine the best RE alternative to develop in the Sumba Barat-Sumba Island zone, solar energy was the best energy alternative with a $C_{i}^{+}$value being closer to 1 compared to the other alternatives. The potential amount of solar energy that can be developed on Sumba Island, which lies in a tropical area, is $10 \mathrm{MW}$ on account of it receiving average sunlight of $5 \mathrm{~kW} \mathrm{~h} / \mathrm{m}^{2} / \mathrm{d}$, with the sun shining for $5 \mathrm{~h}$ a day, and radiation of $1000 \mathrm{~W} / \mathrm{m}^{2}$ with a total area of $11,153 \mathrm{~km}^{2}$ [27].

According to the TOPSIS analysis results presented in Table 4, Sumba Timur does have considerable solar energy potential as in this area, the sun shines almost every day from 7 a.m. to 5 p.m. and the dry season lasts longer than the wet season. It receives way more sunlight than any other island in Indonesia, especially at noon (from about 11 a.m. to 3 p.m. local time). Additionally, Sumba Island has geographic characteristics and hard-to-access hilly topography, causing the solar energy to be the most efficient and effective energy to develop there.

Table 4: $C_{i}^{+}$values.

\begin{tabular}{llrrr}
\hline No. & Energies produced & $\mathbf{S}^{+}$ & $\mathbf{S}^{-}$ & $\boldsymbol{C}_{\boldsymbol{i}}^{+}$ \\
\hline 1 & Solar & $\mathbf{0 . 0 0 2 1 7}$ & $\mathbf{0 . 0 1 2 0 2}$ & $\mathbf{0 . 8 4 7}$ \\
2 & Hydro & $\mathbf{0 . 0 0 2 3 3}$ & $\mathbf{0 . 0 0 8 3 0}$ & $\mathbf{0 . 7 8 1}$ \\
3 & Wind & 0.00300 & 0.00610 & 0.671 \\
4 & Biogas/biomass & 0.00425 & 0.00505 & 0.543 \\
5 & Geothermal & 0.01145 & 0.00146 & 0.113 \\
\hline
\end{tabular}


It is expected that these findings can be a basis for the development of solar-based RE for the energy security of Sumba Timur to be preserved. As stated by Jenner et al. [28], these results can serve as evidence supporting the private interest theory and the public interest theory in the following way: (1) the presence of solar energy association increases the probability of a country to adopt a regulation; (2) solar radiation; (3) the unemployment rate increases opportunities and (4) electricity market concentration reduces the transition probability. This means that solar energy is a business opportunity specific to the private sector enterprises in Sumba Timur. Still, a further review of the technical and business feasibility as well as supporting business policies and model are deemed necessary.

Although solar energy development for strengthening the energy security in the Sumba Timur zone is highly possible based on the TOPSIS analysis results discussed above, the implementation does not go unchallenged. Ansari et al. [29], while implementing a solar energy generation system in India using the Interpretive Structural Modelling (ISM), faced some stumbling blocks, including lack of local infrastructure, lack of political commitment, financial mechanism problems, lack of user awareness and lack of government policy support. Therefore, while conducting solar energy development in Sumba Timur in the future, it is necessary to not only specifically review the business feasibility, but also review the obstacles and supporting government policies using the ISM approach.

\subsection{Solar energy}

The average solar radiation intensity throughout Indonesia is about $4.8 \mathrm{~kW} \mathrm{~h} / \mathrm{m}^{2}$, which indicates its potential for generating electricity and that it can be used as an alternative source of energy. The implementation of solar power generation in Indonesia still faces several hindrances, including high cost of investing, the need to import the photovoltaic modules from abroad and low efficiency of the photovoltaic modules at only $16 \%$, leading to soaring solar energy price per kilowatt. Thus, to improve the rated capacity of solar power plants, the government needs to issue a regulation or add local content to support creating solar power generation devices. The addition of local content will suppress the cost of solar power generation and make it more justifiable to use solar energy as an alternative energy [30].

Solar power plants are useful in many ways: (1) solar energy is free of charge (it requires nearly zero fuel cost); (2) it is modular, allowing for adjustments according to the needs, from a residential scale to a centralised generation scale (utility); (3) it can be built in a short period of time virtually anywhere as long as the sunlight is not blocked by any object; (4) it is automatically operable and remotely controllable through the Internet network; (5) it can offer an oil fuel efficiency solution for the existing genset-based power generation; (6) solar power plant produces electricity from the morning until late afternoon; (7) it can support office, business and industrial activities; (8) it can be adapted to the energy needs and the land availability and (9) solar power plant can be ground mounted, floating or rooftop mounted.

To this day, the people of five villages in Sumba Timur have been able to access clean electricity from solar photovoltaic systems or solar power plants. The five villages are Tawui, Lailunggi, Praimadita, Tandula Jangga and Praiwitu. The $492 \mathrm{kWp}$ capacity solar power plants are able to provide electricity for 852 households and 57 public facilities, and as many as 11 microgrid solar panels have been installed in the five villages [31]. 
Table 5: Realised hydro power use in Sumba Timur.

\begin{tabular}{llllll}
\hline No. & Villages & $\begin{array}{c}\text { Locations } \\
\text { Districts }\end{array}$ & $\begin{array}{l}\text { Power } \\
(\mathbf{k W} \text { h) }\end{array}$ & Year & Institutions \\
\hline 1 & Praingkareha & Tabundung & 35 & 2005 & $\begin{array}{l}\text { Office of Energy and } \\
\text { Human Resources of East } \\
\text { Nusa Tenggara }\end{array}$ \\
2 & Watumbelar & Lewa Tidahu & 21 & 2016 & $\begin{array}{l}\text { Ministry of Energy and } \\
\text { Human Resources } \\
\text { Ministry of Energy and }\end{array}$ \\
& Pinduhurani & Tabundung & 40 & 2017 & $\begin{array}{l}\text { Human Resources } \\
\text { Ministry of Energy and }\end{array}$ \\
& Kuruwaki & Pahunga Lodu & 30 & 2017 & $\begin{array}{l}\text { Human Resources } \\
\end{array}$ \\
& Total & $\mathbf{1 2 6}$ & & \\
\hline
\end{tabular}

Source: Office of Energy and Human Resources of the Province of East Nusa Tenggara, 2018.

\subsection{Hydro power}

East Nusa Tenggara has scores of streams that can be used as sources of energy for hydro power plants or micro-hydro power plants. According to the results of a survey conducted by the Ministry of Energy and Human Resources, the power generated from the water-based power generation can reach $143 \mathrm{MW}$. Such energy is spread in 24 locations across East Nusa Tenggara and can potentially be used at a small to medium scale. However, the micro-hydro power potential has yet to be used optimally in all locations for generating electricity, causing non-optimal harnessing of energy. In the future, all such hydro energy potential will be used for generating RE [32]. To date, there have been 126 hydro power plants in Sumba Timur spread in several districts as presented in Table 5.

\section{CONCLUSION}

The results of the TOPSIS analysis conducted on five potential RE sources in Sumba Timur based on 26 sustainable energy security criteria show that solar energy has the highest potential (0.847). Second most potential energy is hydro power or micro-hydro power (0.781), followed by wind energy (0.671). The total solar energy potential that can be developed is 10 MW on account of Sumba receiving average sunlight of $5 \mathrm{~kW} \mathrm{~h} / \mathrm{m}^{2} / \mathrm{d}$, with the sun shining for $5 \mathrm{~h}$ a day, and radiation of $1000 \mathrm{~W} / \mathrm{m}^{2}$ with a total area of $11,153 \mathrm{~km}^{2}$. The results of this study need a technical follow-up in the form of business and technical feasibility studies and a further study on the business model and management system.

This research is expected to be used as a reference in the successful development of energy security and independence zones in regions or other remote islands in Indonesia, especially in areas that have not been reached or have access to electricity but the potential for renewable natural resources is there. Especially in Indonesia, at the moment, there are thousands of villages that have not been electrified. On the other hand, this research needs to be extended further to study the socioeconomic impact and sustainability of the development of independent energy security zone in East Sumba, as well as for evaluating and revitalising facilities and infrastructure of new and RE programmes on Sumba Island. 


\section{REFERENCES}

[1] Imbert, E., Ladu, L., Morone, P. \& Quitzow, R., Comparing policy strategies for a transition to a bioeconomy in Europe: The case of Italy and Germany. Energy Research \& Social Science, 33, pp.70-81, 2017. https://doi.org/10.1016/j.erss.2017.08.006

[2] Silveria, F.S. \& Luken, R.A., Global overview of industrial energy intensity. Energy Policy Journal, 36, pp. 2658-2664, 2008. https://doi.org/10.1016/j.enpol.2008.03.005

[3] Hivos, Sumba: An Iconic Island to Demonstrate the Potential of Renewable Energy, 2012.

[4] Lomi, A., Pulau Ikonis Energi Terbarukan sebagai Pulau Percontohan Mandiri Energi Terbarukan di Indonesia, Proceedings SENIATI: Green Technology Innovation. https:// ejournal.itn.ac.id/index.php/seniati/article/view/300, pp. 1-6, 2016.

[5] Yasin, A., Ketahanan dan Kedaulatan Energi Indonesia., Jakarta (ID): Info Risiko Fiskal, Pusat Pengelolaan Risiko Fiskal, BKF, Kementerian Keuangan, 1, p. 21, 2014. https://www.djppr.kemenkeu.go.id/uploads/files/IRF/2014_IRF\%20Edisi\%201 \%20Tahun\%202014.pdf

[6] International Energy Agency (IEA). Ensuring the Uninterrupted Availability of Energy Sources at an Affordable Price, 2017. https://www.iea.org/topics/energy-security (accessed on 23 April 2018).

[7] Sekretariat Jenderal Dewan Energi Nasional [SJDEN]. Indonesia Energy Outlook Online Version 2016. Jakarta (ID), https://den.go.id/index.php/publikasi/download/49 (accessed on 23 April 2018)

[8] Yulianto, B., Maarif, M.S., Wijaya, C. \& Hardjomidjojo, H., Energy security scenario based on renewable resources: A case study of East Sumba, East Nusa Tenggara, Indonesia. International Journal of Administrative Science \& Organization, 26(1), pp. 10-22, 2019. doi:10.20476/jbb.v26i1.10170

[9] Azmi, R. \& Amir, H., Keuangan Ketahanan Energi: Konsep, Kebijakan dan Tantangan bagi Indonesia. Jakarta (ID): Info Risiko Fiskal, Pusat Pengelolaan Risiko Fiskal, BKF, Kementerian Keuangan Republik Indonesia, 1, pp. 4-5, 2014. https://www.djppr. kemenkeu.go.id/uploads/files/IRF/2014_IRF\%20Edisi\%201\%20Tahun\%202014.pdf

[10] World Energy Council, World Energy Trilemma Index 2018. https://www.worldenergy. org/assets/downloads/World-Energy-Trilemma-Index-2018.pdf (accessed on 8 april 2018)

[11] Barzola, J., Espinoza, M. \& Cabrera, F., Analysis of hybrid solar/wind/diesel renewable energy system for off-grid rural electrification. International Journal of Renewable Energy Research, 6(3), pp. 1146-1152, 2016.

[12] Stoms, D.M., Dashiell, S.L. \& Davis, F.W., Siting solar energy development to minimize biological impacts. Renewable Energy, 57, pp. 289-298, 2013. https://doi. org/10.1016/j.renene.2013.01.055

[13] Kiesecker, J.M., Evans, J.S., Fargione, J., Doherty, K., Foresman Kunz, T.H., Nugle, D., Nibbelink, N.P. \& Niemuth, N.D., Win-win for wind and wildlife: A vision to facilitate sustainable development. PLOS ONE, 6(4), 2011. https.//doi.10.1371/journal. pone.0017566

[14] California Public Utilities Commission, Renewable Energy Transmission Initiative (RETI) Phase 2A Final Report., 2009. https://ww2.energy.ca.gov/2009publications/ RETI-1000-2009-001/RETI-1000-2009-001-F-REV2.PDF (accessed on 8 April 2018)

[15] Argonne National Laboratory, Resilience Measurement Index: An Indicator of Critical Infrastructure Resilience., 2013. https://publications.anl.gov/anlpubs/2013/07/76797. pdf (accessed on 8 April 2018) 
[16] Electricity Reliability Council of Texas (ERCOT). Competitive Renewable Energy Zones Transmission Optimization Study, Texas: Technical report, Electricity Reliability Council of Texas, 2008. https://www.nrc.gov/docs/ML0914/ML091420467.pdf (accessed on 2 March 2018)

[17] Hermann, S., Miketa, A., \& Fichaux, N., Estimating the renewable energy potential in Africa - A GIS-based approach, IRENA-KTH working paper, Abu Dabi (SA): Technical report, International Renewable Energy Agency (IRENA), 2014. irena.org/ publications/2014/Aug/Estimating-the-Renewable-Energy-Potential-in-Africa-A-GISbased-approach (accessed on 2 Mar 2018)

[18] Council for Scientific and Industrial Research, Strategic search for SA's best wind and sun, Council for Scientific and Industrial Research, 2014.

[19] Rijanto, M.W. \& Armawi, A., Peran PEMDA dan Masyarakat dalam Pengembangan Energi Alternatif Terbarukan untuk mendukung ketahanan energi (Studi di Kabupaten Sumedang, Jawa Barat), Jurnal Ketahanan Nasional, 16(3), pp. 25-51, 2011. https:// doi.org/10.22146/jkn. 16860

[20] Popescu, M.F., The economics and finance of energy security. Procedia Economics and Finance, 27, pp. 467-473, 2015. https://doi.org/10.1016/S2212-5671(15)01022-9

[21] Kanchana, K. \& Unesaki, H., ASEAN energy security: An indicator-based assessment, Energy Procedia., 56, pp. 163-171, 2014. https://doi.org/10.1016/j.egypro.2014.07. 145

[22] Kulkarni, S.H., Anil, T.R. \& Gowdar, R.D., Wind energy development in India and a methodology for evaluating performance of wind farm clusters. Journal of Renewable Energy, 2016, pp.1-11, 2016. https://doi.org/10.1155/2016/6769405

[23] Hwang, C.L. \& Yoon, K., Multiple Attribute Decision Making: Methods and Applications, Springer-Verlag: New York, 1981. http://dx.doi.org/10.1007/978-3-642-48318-9

[24] Yuniarti, S., Sistem Pendukung Keputusan Penentuan Prioritas Media Promosi Menggunakan Fmadm Dengan Metode Simple Additive Weighting (Studi kasus: STMIK Profesional Makassar), Program Studi Ilmu Komputer Universitas Gadjah Mada Yogyakarta.Yogyakarta (ID): UGM, Unpublished Thesis, 2011.

[25] Maarif, S.M. \& Tanjung, H., Manajemen Operasi, PT. Grasindo, Jakarta. 2003.

[26] Eswarlal, V.K., Dey, P.K. \& Shankar, R., Enhanced renewable energy adoption for sustainable development in India: Interpretive structural modeling approach. World Renewable Energy Congress-Sweden, Linkoping, Sweden. May 2011.

[27] Syahni, D., Program Listrik Energi Terbarukan Sumba, Bagaimana Perkembangannya, http://www.mongabay.co.id/2017/11/10/program-listrik-energi-terbarukan-sumbabagaimana-perkembangannya/ (accessed on: 1 October 2018).

[28] Jenne, S., Chana, G., Frankenbergerb, R. \& Gabelb, M., What drives states to support renewable energy? The Energy Journal, 33(2), pp. 1-12, 2012.

[29] Ansari, M.F., Kharb, R.K., Luthra, S., Simmi, S.L. \& Chaterji, S., Analysis of barriers to implement solar power instalations in India using Interpretive Structural Modeling Technique. Renewable and Sustainable Energy Reviews, 27, pp. 163-174. 2013. https:// doi.org/10.1016/j.rser.2013.07.002

[30] Rahardjo, I., \& Fitriana, I., Analisis Potensi Pembangkit Listrik Tenaga Surya di Indonesia. Strategi Penyediaan Listrik Nasional dalam Rangka Mengantisipasi Pemnafaatan PLTN Batubara Skala Kecil, dan Energi Terbarukan. https://www.oocities.org/markal_ bppt/publish/pltkcl/plrahard.pdf, pp. 43-52, 2013. 
[31] Millenium Challenge Account [MCA], Akses Listrik Bersih 500 kWp untuk Desadesa Terpencil di Sumba Timur, http://www.mca-indonesia.go.id/assets/uploads/ news/180411\%20GP\%20Anekatek\%20Sumba\%20ID.pdf, 2018.

[32] Fauzi, A.R. \& Sugita, M.R.P., Studi Impementasi Smart Grid dengan Penetrasi Hybrid Renewable Energy di Provinsi Nusa Tenggara Timur. Presented at Konferensi Smart Grid Indonesia, 2016. 